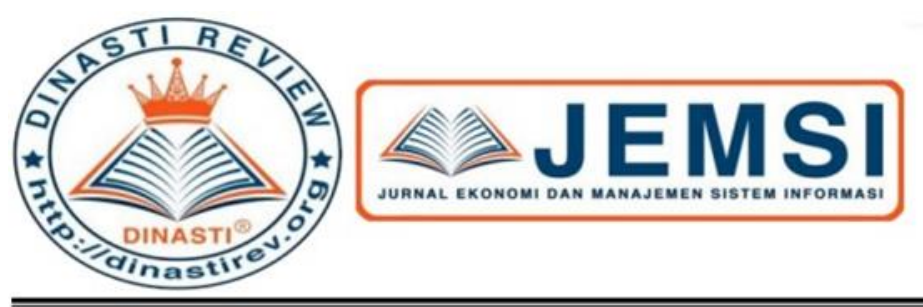

$+62878-9658-6407$ (C)

087896586407 ().

https://dinastirev.org/JEMSI (-)

editor@dinastirev.org@.

\title{
ANALISIS SWOT PENGEMBANGAN INDUSTRI KONVEKSI PERUSAHAAN KOGAYA DALAM MENGHADAPI BARANG IMPORT DARI CHINA
}

\section{Lucky Safitri}

Universitas Mercubuana Jakarta Indonesia

ARTICLE INFORMATION

Received: 17 April 2020

Revised: 20 Mei 2020

Issued: 7 Juli 2020

Corresponding author: Lucky

\section{Safitri}

E-mail:

lunasafitri18@gmail.com

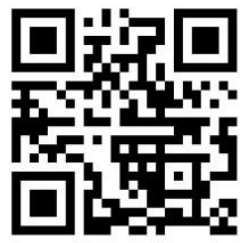

DOI:10.31933/JEMSI
Abstrak: Konveksi Kogaya adalah perusahaan yang bergerak pada bidang Industri pakaian jadi, tujuan dari penelitian ini adalah untuk menganalisis kondisi internal dan eksternal perusahaan guna memperoleh keunggulan bersaing bagi perusahaan sehingga mampu bersaing menhgadapi import dari China. Metode yang digunakan pada penelitian ini yaitu metode deskriptif dengan alat analisis SWOT. Teknik pengumpulan data menggunakan wawancara yang dilakukan terhadap pihak-pihak terkait di dalam perusahaan. Data-data yang telah diperoleh tersebut dianalisis menggunakan deskriptif analisis swot. Srategi menunjukkan alternatif yang dapat diterapkan perusahaan adalah strategi marketing, operasional dan finance. Hasil akhir penelitian ini menyimpulkan bahwa bagaimana perusahaan mampu memiliki strategi dalam menghadapi barang import dari China kususnya yaitu yang diperoleh dari hasil analisis SWOT.

Kata Kunci: Manajemen Strategi, Analisis SWOT, Industri, Import, Konveksi.

\section{PENDAHULUAN}

Negara Indonesia adalah negara dengan dominan penduduk beragama islam yaitu dari data Statistics Indonesia Population Census (indonesia-investments.com, 2010) sebesar 87.2\% berdasarkan banyaknya jumlah penduduk Indonesia dan 207.2 juta orang lainnya beragama Muslim. Hal ini mendorong pelaku usaha di Indonesia khususnya di bidang pakaian jadi untuk memproduksi pakaian jadi bernuansa islami atau biasa dikenal dengan fashion muslim. Salah satu pusat bisnis yang menjadi sentral perdagangan di Indonesia adalah Pasar Tanah Abang yang berada di Kota Jakarta Indonesia yang merupakan pusat perbelanjaan grosir yang terbesar (Kompas.com). Karena memiliki tingkat penjualan yang tinggi dan terbesar se-Asia Tenggara (tribuntravel.com, 2019). Kondisi diatas mendorong pelaku usaha untuk dapat memproduksi pakaian dan membuka peluang usaha konveksi mengingat besarnya peluang yang ada terutama pada Pasar Tanah Abang tanpa terkecuali dari perusahaan konveksi Kogaya.

Kogaya merupakan perusahaan konveksi yang berdiri dari tahun 2008 hingga saat ini yang terkosentrasi pada produksi pakaian jadi muslim. Usaha konveksi diawali dari hobby sang pemilik konveksi menggambar pola design baju serta mempunyai rasa keinginan yang kuat untuk mampu menjadi seorang pengusaha sejak menempuh Sekolah Menengah Pertama (SMP) serta. Dengan mengembangkan hobby tersebut, pemilik mampu mengembangkan usaha 
konveksi dengan brand kogaya, dengan mengeluarkan brand fashion muslim KOGAYA, dimana perusahaan ini berdiri dimaksudkan untuk memperoleh pasar Indonesia khususnya dan dunia dengan target market middle income. Pasar Tanah Abang menjadi pilihan utama untuk pendistribusian produksi. Berada di tengah kota Tangerang, konveksi ini telah memiliki 28 orang tukang jahit professional, satu designer dan satu orang tenaga administrasi.

Seiring perkembangannya konveksi ini mampu bertaham dan berkembang sampai saat ini, hal tersebut dilihat berdasarkan hasil perolehan income yang terus meningkat serta kesejahteran karyawan yang cukup bagus. Namun ditengah persaingan global konveksi Kogaya mengalami penurunan omset untuk tiga tahun terkahir, hal ini di dominasi oleh faktor besarnya arus perdagangan dari negara luar yang datang dan memasuki wilayah Indonesia, terutama dalam hal menguasai Pasar Tanah Abang. Pedagang pada pasar Tanah Abang lebih dominan membeli pakaian jadi muslim import dari Cina karena memiliki harga dibawah pasaran daripada produk konveksi dalam Negeri. Seperti yang diungkapkan Ketua API (Asosiasi Per-tekstilan Indonesia Ade Sudrajat bahwa pakaian import dari China lebih murah 10-20\% dibandingkan buatan local (detikFinance, 2019)

Dengan latar belakang kondisi diatas maka mendorong peneliti untuk dapat memahami apa yang menjadi kekuatan serta kelemahan pada perusahaan konveksi khususnya konveksi Kogaya sehingga juga dapat mengidentifikasi tantangan dan peluang dari perkembangan bisnis yang terjadi dengan kondisi seperti ini. Karena kondisi ini harus menjadi perhatian khusus bagi usaha kecil dan menengah tanpa terkecuali usaha konveksi Kogaya yang merupakan satu diantara sekian banyak usaha konveksi kecil dan menengah yang sedang berkembang dan terus berusaha bertahan ditengah persaingan global yang semakin pesat.

\section{KAJIAN PUSTAKA}

Pesatnya perkembangan pemasaran global membuat perusahaan tekstil dan industri konveksi ditanah air ikut berimbas, tanpa terkecuali perusahaan Kogaya. Menurut UndangUndang No. 5 pada Tahun 1984 mengenai Perindustrian dalam Atikah (2014) industri merupakan kegiatan ekonomi didalam mengolah bahan mentah, bahan baku, barang setengah jadi, ataupun barang jadi menjadi barang dengan nilai yang lebih tinggi untuk penggunaannya, termasuk kegiatan rancang bangun dan perekayasaan industri. Secara etimologi industri "kerajinan, aktivitas". Sementara itu konveksi berbeda dengan garmen dan penjahit rumahan. Menurut Brian (2020) konveksi merupakan tempat atau lokasi yang dijadikan khusus sebagai lokasi produksi sebuah brand yang ada hubungannya dengan keperluan sandang manusia. Beberapa jenis yang dapat dibuat pada bisnis-bisnis konveksi yaitu seperti; T-shirt, jacket, celana, seragam, topi, dan jenis fashion lainnya. Bisnis konveksi mampu memproduksi dalam jumlah berkodi- kodi. Berbeda dengan penjahit-penjahit yang dirumah biasanya hanya mampu menyelesaikan beberapa pcs saja. Sedangkan dalam type garmen skala yang mampu dihasilkan dapat lebih besar jika dibanding skala yang dihasilkan konveksi. Hal tersebut dikarenakan dalam type garmen system pengerjaannya memiliki lebih banyak karyawan dan juga memiliki peralatan yang lengkap. Antara penjahit rumahan, konveksi, dan garmen juga memiliki perbedaan yang dapat terlihat jauh berbeda berberdasarkan kuantitas produksinya dapat diuraikan seperti:

1. Penjahit dalam type rumahan hanya dapat memperoleh sekitar $1 \mathrm{~s} / \mathrm{d} 5 \mathrm{pcs}$.

2. Penjahit dalam type konveksi mampu memperoleh lebih banyak dari penjahit type rumahan, sekitar 12 sampai dengan 10.000 pcs karena memiliki beberapa karyawan dengan jumlah kuantitas yang lebih besar dan dilengkapi beberapa peralatan.

3. Penjahit dalam type Garmen mampu memperoleh hasil produksi yang lebih banyak dari type konveksi yaitu lebih dari 10.000 pcs. Hal tersebut dikarenakan type Garmen memiliki karyawan yang lebih profesional dan juga dilengkapi dengan fasilitas peralatan yang lebih lengkap dan modern juga memiliki ketentuan jam kerja tertentu.

(Maxmanroe.com, 2020) 
Berkembangnya pemasaran global dan mudahnya barang import masuk ke Indonesia mengakibatkan tingginya persaingan didunia bisnis, Menurut Basu Swasta (2009) pemasaran Global adalah pemasaran yang seluas dunia dimana peluang pasar akan selalu terbuka bagi semua pelaku usaha. Menyebabkan pemasaran tidak hanya menjangkau daerah setempat saja melainkan sampai ke seluruh dunia. (pengertianparaahli.org, 2020)

Hal ini membuat Kogaya sebagai salah satu industri konveksi menengah di Indonesia melakukan langkah strategis yang dirumuskan dalam management strategic, Hal ini dimaksudkan agar perusahaan dapat terus berdiri dan berkembang menghadapi persaingan global. Dalam Farida, et al (2019) Internal brand assessment juga berguna untuk menyelaraskan kekuatan brand di mata pihak internal maupun eksternal, sehingga tidak tejadi perbedaan pemahaman tentang brand antara pihak internal dan eksternal. Menurut Jauch dan Gluech (1998) Manajemen Strategik merupakan sejumlah keputusan dan tindakan yang mengarah pada penyusunan sejumlah strategi yang efektif dalam membantu mencapai sasaran perusahaan. Sementara itu Solihin (2012) mengatakan bahwa proses perencanaan, pengarahan (directing), pengorganisasian dan pengendalian berbagai keputusan dan tindakan strategi perusahaan dengan tujuan untuk mencapai keunggulan kompetitif merupakan pengertian dari manajemen strategis. Efektivitas organisasi dalam mencapai tujuannya sangat dipengaruhi oleh kualitas sumber daya manusia yang dimiliki. Organisasi harus memiliki karyawan yang kompeten dan efektif untuk mencapai tujuannya (Purba, et al, 2018)

Menurut Fadli (2019) Alat yang dipakai untuk menyusun faktor-faktor strategis perusahaan adalah matrik SWOT. Matrik ini dapat menghasilkan 4 set kemungkinan alternatif strategis. Strategi SO (Strength-Opportunities) Strategi yang dibuat berdasarkan tujuan perusahaan, yaitu dengan memanfaatkan kekuatan yang dimiliki secara keseluruhan untuk mendapatkan dan memanfaatkan peluang yang sebesar-besarnya. Adapun unsur Analisis SWOT diantaranya:

1. Kekuatan (Strength) Analisis terhadap perusahaan melalui unsur kekuatan yang dimiliki. Seperti menganalisis tentang kelebihan yang dimiliki perusahaan dari segi teknologi, kualitas hasil produksi, lokasi strategis, atau unsur kekuatan lainnya yang lebih menekankan pada keunggulan perusahaan.

2. Kelemahan (Weakness) Selain melihat perusahaan dari unsur kekuatan, sangat penting juga untuk memahami apa kelemahan yang dimiliki. Dalam mengetahui kelemahan perusahaan tentunya harus melakukan perbandingan dengan pesaing mengenai apa yang dimiliki dan tidak dimiliki oleh perusahaan. Untuk membuat daftar kelemahan perusahaan agar lebih obyektif dengan melakukan testimoni kepada konsumen.

3. Peluang (Opportunity) Unsur peluang dapat dibuat saat membangun suatu bisnis. Karena dalam membuat atau membentuk sebuah bisnis tentunya didasarkan dengan adanya kesempatan atau peluang sehingga memiliki tujuan untuk memperoleh keuntungan dari bisnis yang akan dibuat.

4. Ancaman (Threats) Analisis ini tentunya sangat diperlukan karena akan berdampak pada seberapa lama jangka yang akan ditempuh bisnis ini dan mampukan bisnis ini bertahan dalam jangka yang panjang.

Dalam menghadapi persaingan dunia bisnis tentunya memerlukan strategi yang tepat agar dapat memenangkan persaingan tersebut, dan agar mampu memberikan perhatian kepada lingkungan merupakan cara terbaik untuk merumuskan strategi yang akan diterapkan dalam menghadapi persaingan yang ada baik lingkungan internal maupun eksternal. Menurut David (2009) lingkungan internal adalah seluruh organisasi yang mempunyai kekuatan dan kelemahan dalam berbagai bidang fungsional bisnis. Analisis lingkungan eksternal terhadap peluang dan ancaman tidak cukup untuk memberikan organisasi keuntungan kompetitif. Analisis lingkungan internal yang dilakukan hasilnya akan lebih tertuju pada analisis perusahaan secara internal dalam mengetahui kekuatan juga kelemahan divisi yang dimiliki. 
Menurut Pearce \& Robinson dalam Kotler (2005) analisis lingkungan internal merupakan pengertian mengenai pencocokan kekuatan dan kelemahan internal dengan peluang serta ancaman eksternal. Hasil dari analisis lingkungan internal akan memperoleh kekuatan dan kelemahan dari perusahaan tersebut untuk dijadikan ciri khas yang dapat dijadikan keunggulan yang dimiliki perusahaan dan digunakan dalam membuat keunggulan pada bagian pemasaran, sumber daya manusia, keuangan, operasional dan divisi lainnya.

Dalam hal ini untuk mengkaji lingkungan internal dan eksternal dapat dilakukan analisis SWOT pada industri kovekesi kogaya, dimana Analisis SWOT menurut Kotler (2003) evaluasi adalah terhadap semua kekuatan, kelemahan, peluang, dan ancaman, yang terdapat pada individu atau organisasi. Analisis ini bertujuan untuk mengidentifikasi berbagai faktor secara sistematis untuk merumuskan strategi perusahaan. Menurut Hartono (2005) Analisis SWOT digunakan untuk menilai kekuatan kekuatan dan kelemahan kelemahan dari sumber sumber daya yang dimiliki perusahaan dan kesempatan kesempatan eksternal dan tantangan tantangan yang dihadapi. Sedangkan Menurut Kotler \& Armstrong (2008) Analisis SWOT adalah penilaian menyeluruh terhadap kekuatan (strengths) kelemahan (weaknesses), peluang (opportunities), dan ancaman (threats) suatu perusahaan. 'Analisis SWOT bisa dikatakan analisis yang berdasarkan pada anggapan bahwa suatu strategi yang efektif berasal dari sumber daya internal (strength dan weakness) dan eksternal (opportunity dan threat). Keuntungan dari analisis SWOT yaitu dapat menghubungkan faktor internal dan eksternal untuk mendapatkan strategi baru, oleh karena itu perencanaan yang berdasarkan sumber daya dan kompetensi dapat memperkaya analisis SWOT dengan mengembangkaan perspektif internal (Dyson, 2002).

Berdasarkan pernyataan tersebut dapat disimpulkan bahwa Analisis SWOT merupakan sebuah metode yang digunakan untuk dapat dijadikan evaluasi bagi perusahaan apa saja yang menjadi kekuatan dan kelemahan serta mengetahui peluang juga ancaman yang pada bisnis yang dijalani. Pada umumnya analisis SWOT digambarkan dengan tabel pada ukuran kertas yang besar hal tersebut dilakukan guna memudahkan analisis hubungan antar aspeknya. Pembuatan analisis SWOT melibatkan tujuan bisnis yang spesifik dan identifikasi faktor internal-eksternal dalam mencapai tujuan tersebut. SWOT adalah analisis yang dilakukan perusahaan dalam mengidentifikasi kekuatan, kelemahan, peluang dan ancaman yang akan dilakukan guna membantu untuk mengembangkan strategi bisnis, membangun dan mengembangkan perusahaan menjadi lebih baik lagi. Diagram Analisis SWOT terdiri atas 4 daerah kuadran seperti tampak pada gambar berikut ini:

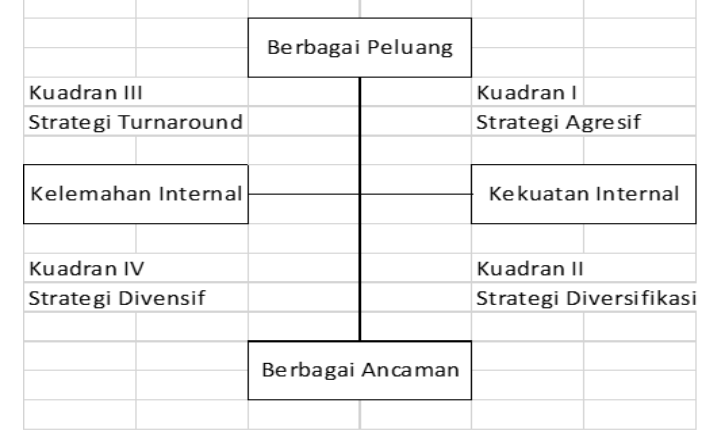

(Sumber: Maxmanroe.com)

1) KUADRAN 1: Situasi yang sangat menguntungkan karena binis tersebut memiliki kekuatan dan peluang yang dapat memanfaatkan. Strategi yang diterapkan dalam kondisi ini adalah dengan mendukung kebijakan pertumbuhan yang agresif. (Growth Oriented Strategy).

2) KUADRAN II: Dengan menghadapi berbagai ancaman, dari segi internal bisnis yang dijalani masih memiliki kekuatan. Strategi yang harus diterapkan adalah menggunakan kekuatan untuk memanfaatkan peluang yang dimiliki dalam jangka panjang dengan cara strategi diversifikasi (produk atau jasa). 
3) KUADARAN III: Perusahaan menghadapi peluang pasar yang sangat besar, tetapi dilihat dari beberapa pihak yang lain perusahaan juga menghadapi beberapa masalah atau kelemahan internal. Fokus perusahaan ini adalah meminimalkan kendala atau masalah dari internal perusahaan sehingga dapat merebut peluang pasar yang lebih baik.

4) KUADRAN IV: Merupakan situasi atau keadaan yang sangat tidak menguntungkan perusahaan karena dimana pada situasi ini perusahaan menghadapi berbagai ancaman dan kelemahan internal.

Terdapat dua langkah utama yang dapat dilakukan untuk melaksanakan analisis SWOT, yaitu:

1. Pertama, jelaskan keempat komponen utama dari analisis SWOT (kekuatan, kelemahan, peluang, dan risiko).

2. Kedua, setelah menguraikan keempat faktor tersebut, maka langkah selanjutnya adalah membuat strategi berdasarkan dengan matriks SWOT.

(Rumus.co.id, 2020)

\section{METODE PENELITIAN}

Metode penulisan yang digunakan dalam artikel ini adalah metode deskriptif, yaitu menyajikan data menganalisis dan menginterpretasikan berdasarkan implementasi terhadap kebijakan perusahaan yang dapat menggambarkan kekuatan, kelemahan, ancaman dan peluang perusahaan. Whintney (1960) proses panjang untuk mengumpulkan fakta harus sesuai dengan interpretasi data-data yang tepat. Arti singkatnya, dalam penelitian dalam model penulisan ini yaitu dengan menggunakan data yang diambil berdasarkan aktivitas, kegiatan, dampak serta hubungan yang ada dalam masyarakat. Menurut Sugiyono dalam parashakti dan Putriawati (2020) analisis deskriptif adalah statistik yang digunakan untuk menganalisis data dengan cara mendeskripsikan atau menggambarkan data yang telah terkumpul sebagaimana adanya tanpa bermaksud membuat kesimpulan yang berlaku untuk umum atau generalisasi. Sebagian besar metode pengumpulan data dan informasi yang digunakan dalam kajian ini didapatkan dilakukan secara langsung melalui data sekunder, dan berbagai referensi yang berkaitan dengan analisis SWOT melalui buku, jurnal, dan artikel. Setelah informasi dikumpulkan dan dianalisis, dideskripsikan dan dibahas kemudian disusun laporan yang diharapkan dapat menjadi gambaran yang cukup komprehensif dari analisis Perusahan Konveksi Kogaya Tangerang Indonesia.

\section{HASIL DAN PEMBAHASAN}

Setelah mengetahui SWOT pada perusahaan konveksi Kogaya. Berikutnya dapat dilakukan analisa seiring dengan perkembangan meningkatnya ilmu pengetahuan dan teknologi, serta arus globalisasi yang tak terbendung, menyebabkan pemasaran tidak hanya menjangkau daerah setempat saja melainkan sampai ke seluruh dunia. Menentukan strategi pemasaran adalah langkah yang harus menjadi perhatian utama ketika menghadapi pemasaran global, Karena strategi pemasaran adalah hal yang sangat penting bagi perusahaan dimana strategi pemasaran.

Melihat situasi saat ini dimana pemasaran global yang semakin meningkat membuat Kogaya sebagai konveksi brand muslim Indonesia harus mampu menggali segala potensi yang dimiliki agar terus bertahan dan mampu bersaing ditengah kompetitor. Adapun kompetitor utama yang menjadi pusat perhatian adalah dari negara China, dimana China telah menguasai pasar secara global, Sebagaimana yang dikatakan Muhammad Idris pada tanggal 3 Mei 2017 Industri tekstil dan produk tekstil (TPT) didalam negeri selama ini cukup terpukul dengan 
serbuan barang impor. Saat ini bahan baku seperti kain yang digunakan industri TPT domestik, sebanyak 70\% berasal dari import (detik.com, 2017). Selain itu menurut Ade sudrajat Ketua Umum Asosiasi Pertekstilan Indonesia (API), banjirnya barang tekstil impor karena banyak negara produsen "membuang" kelebihan produksinya ke berbagai negara, termasuk Indonesia.

Produk tersebut memiliki harga yang jauh lebih murah, bahkan dijual hanya $10 \%$ dari harga jual sebenarnya. Lantaran barang seperti kain yang berlebih dari negara asal tersebut merupakan kualitas B atau B grade. Dengan harga yang menarik ini membuat konsumen di Indonesia tertarik untuk lebih memilih produk import China dan yang paling menonjol yaitu import barang dari negara China. Menurut Asosiasi Pertekstilan Indonesia (API) pada hari Selasa (14/5/2019) Hal itu bisa terjadi karena harga pakaian impor dari China lebih murah 10$20 \%$ dibandingkan buatan lokal. Ketua API Ade Sudrajat mengatakan, harga yang lebih bersaing itu membuat importir lokal memilih mengorder pakaian yang diproduksi negara tersebut. Oleh karena itu beliau menyarankan agar pemerintah mulai membatasi impor tersebut agar industri dalam negeri bisa bertahan (detikFinance.com, 2019). Sebagaimana sudah di atur dalam undang undang tentang undang undang perdagangan dan eksport import yaitu Undangundang Kepabeanan No.10 Tahun 1995.

Berdasarkan data yang diperoleh dari Kementerian Perindustrian bahwa impor bahan baku tekstil pada tahun 2016 tercatat sebesar US\$ 6,7 miliar, mengalami peningkatan dari tahun 2015 sebesar US\$ 6,51 miliar. Sementara import pada periode Januari-Februari 2017 yakni sebesar US\$ 1, 38 miliar, mengalami penurunan dari import di periode yang sama tahun lalu yakni US\$ 1,07 miliar. Import bahan baku tekstil tersebut seperti kain sutera, serat tekstil, serat stapel, benang filamen, benang tenun, benang rajut, sulaman atau bordir, dan kain lainnya. Sementara untuk import produk pakaian jadi tahun 2016 tercatat sebesar US\$436,33 juta, atau dapat dikatakan meningkat 4,39\% dibandingkan tahun 2015 yakni US\$ 421,61 juta. Untuk import pakaian jadi pada periode Januari-Februari 2017 sebesar US\$77,53 juta dapat dikatakan meningkat 2,39\% dibandingkan periode yang sama tahun 2016 sebesar US\$ 75,72 juta. Data tersebut memperlihatkan bahwa begitu mudah dan besarnya kemampuan yang dimiliki Negara China dalam mengimport bahan baku tekstil ke Indonesia dan menjadikan ini sebagai tantangan bagi Konveksi Kogaya dalam meraih perhatian pasar.

Adapun perusahaan Kogaya telah memiliki beberapa sumber daya yang berpotensi untuk dapat dikembangkan sebagai konveksi unggulan tanah air, antara lain dapat diuraikan melalui Analisis SWOT berikut ini:

Menurut Rangkuti, dalam Rahmayati (2002)

1) Disusun faktor-faktor yang menjadi peluang dan ancaman.

2) Dilakukan pemberian nilai dari 1,00 hingga 0,00 (dari sangat penting hingga tidak penting) yang tergantung pada besarnya faktor dampak yang ada.

3) Dilakukan pemberian rate 4-1 untuk peluang (peluang yang besar).

4) Dilakukan pemberian rate 1-4 untuk ancaman (ancaman yang besar).

5) Dilakukan perkalian antar nilai dengan rating sehingga diperoleh nilai untuk setiap faktor.

6) Nilai setiap faktor di jumlahkan sehingga diperoleh nilai total untuk faktor strategi eksternal. Nilai ini menunjukkan bagaimana perusahaan bereaksi terhadap faktor-faktor eksternalnya dan dapat digunakan sebagai pembanding untuk perusahaan sejenis.

\section{Identifikasi Lingkungan Internal dan eksternal}


Gambar 1: Kerangka SWOT Perusahaan Konveksi "Kogaya"

\begin{tabular}{|l|l|}
\hline Kekuatan (Strength) & Kelemahan (Weaknes) \\
\hline Konveksi sudah dimilki sendiri & Kurang melakukan promosi \\
\hline $\begin{array}{l}\text { Dapat pesan Custom dan harga yang terjangkau } \\
\text { serta kwalitas bagus }\end{array}$ & $\begin{array}{l}\text { Sebagian dari kapasitas mesin } \\
\text { jahit adalah mesin jahit tra disional } \\
\text { dan telah lama }\end{array}$ \\
\hline Sudah lengkap saran dan pransarana konveksi & Turn over pegawai yang tinggi \\
\hline Cepat dan tepat waktu dalam pengerjaan & $\begin{array}{l}\text { Besarnya biaya yang tidak } \\
\text { terduga }\end{array}$ \\
\hline Memiliki tenaga kerja yang handal & $\begin{array}{l}\text { Pemilik Konveksi Terjun } \\
\text { langsung, merangkap ke beberapa } \\
\text { bagian }\end{array}$ \\
\hline Peluang(Opportunity) & Tantangan (Threats) \\
\hline $\begin{array}{l}\text { Indonesia cukup kuat di pakaian jadi segmen } \\
\text { menengah khususnya baju muslim }\end{array}$ & $\begin{array}{l}\text { Kenaikan harga bahan baku } \\
\text { sering tiba tiba }\end{array}$ \\
\hline $\begin{array}{l}\text { Tanah Abang Central Perdagangan terbesar se } \\
\text { Asia tenggara }\end{array}$ & $\begin{array}{l}\text { Import barang dari China yang } \\
\text { tinggi }\end{array}$ \\
\hline Media Online sedang di gandrungi & \\
\hline
\end{tabular}

\section{Matriks SWOT}

Menurut Rangkuti dalam Handayani dan Ali (2006), Matriks SWOT dapat menggambarkan secara jelas bagaimana peluang dan ancaman eksternal yang dihadapi perusahaan dapat disesuaikan dengan kekuatan dan kelemahan yang dimilikinya. Matriks ini dapat menghasilkan empat kemungkinan altenatif strategis.

\begin{tabular}{|c|c|c|}
\hline & & \\
\hline & $\mathbf{S}$ & w \\
\hline $\mathbf{O}$ & $\begin{array}{l}\text { Terus meningkatkan kualitas baik dari } \\
\text { design, bahan. }\end{array}$ & $\begin{array}{l}\text { Meningkatkan promosi } \\
\text { dengan memanfaatkan media } \\
\text { sosial seperti } \\
\text { Facebook,Instagram yang } \\
\text { berbayar }\end{array}$ \\
\hline & $\begin{array}{l}\text { Melakukan penelitian untuk penentuan } \\
\text { harga }\end{array}$ & $\begin{array}{l}\text { Menambah Upah pada } \\
\text { pegawai untuk menurunkan } \\
\text { Turnover }\end{array}$ \\
\hline & $\begin{array}{l}\text { Memperluas Pasar dengan membuka } \\
\text { sistem keagenan dan resller }\end{array}$ & $\begin{array}{l}\text { Mencatat dan } \\
\text { mendokumentasikan } \\
\text { pengeluaran dan pemasuka } \\
\text { setiap transaksi }\end{array}$ \\
\hline & $\begin{array}{l}\text { Memproduksi sesuai dengan permintaan } \\
\text { pasar yang semakin besar }\end{array}$ & \\
\hline $\mathbf{T}$ & $\begin{array}{l}\text { Mengontrol pembelian bahan baku dan } \\
\text { membeli bahan baku dari tangan } \\
\text { pertama }\end{array}$ & $\begin{array}{l}\text { Owner melakukan } \\
\text { pengawasan produknya } \\
\text { secara langsung }\end{array}$ \\
\hline & $\begin{array}{l}\text { Mengutamakan kepuasan pelanggan } \\
\text { dengan kualitas produk }\end{array}$ & $\begin{array}{l}\text { Dengan pengalaman yang } \\
\text { dimiliki owner dapat } \\
\text { memotivasi pewagainya untuk } \\
\text { terus semangat berkerja. }\end{array}$ \\
\hline & Membuat laporan bulanan pegawai & \\
\hline
\end{tabular}

\section{Perhitungan SWOT}


Volume 1, Issue 6, Juli 2020,

\begin{tabular}{|l|c|l|r|}
\hline Faktor internal (Strength) & Rating & Weight & $\begin{array}{l}\text { Weighted } \\
\text { score }\end{array}$ \\
\hline Konveksi sudah dimilki sendiri & 3 & 0,03 & 0.09 \\
\hline $\begin{array}{l}\text { Dapat pesan Custom dan harga } \\
\text { yang terjangkau serta kwalitas } \\
\text { bagus }\end{array}$ & 3 & 0,03 & 0.09 \\
\hline $\begin{array}{l}\text { Cepat dan tepat waktu dalam } \\
\text { pengerjaan }\end{array}$ & 2 & 0,03 & 0.06 \\
\hline $\begin{array}{l}\text { Memiliki tenaga kerja yang } \\
\text { handal }\end{array}$ & 4 & 0.2 & 0.8 \\
\hline
\end{tabular}

\begin{tabular}{|l|c|l|l|}
\hline & & & \\
\hline Faktor internal ( Weaknes ) & Rating & Weight & Weighted score \\
\hline & & & \\
\hline Kurang melakukan promosi & 3 & 0,2 & 0.6 \\
\hline $\begin{array}{l}\text { Sebagian dari kapasitas mesin jahit adalah mesin } \\
\text { jahit tradisional dan telah lama }\end{array}$ & 3 & 0,01 & 0.03 \\
\hline Turn over pegawai yang tinggi & 2 & 0,09 & 0,18 \\
\hline Besarnya biaya yang tidak terduga & 4 & 0,2 & 0,8 \\
\hline $\begin{array}{l}\text { Pemilik Konveksi Terjun langsung, merangkap } \\
\text { ke beberapa bagian }\end{array}$ & 3 & 0,01 & 0,03 \\
\hline Total & 31 & 1 & 3,3 \\
\hline
\end{tabular}

\begin{tabular}{|l|r|r|r|}
\hline Faktor eksternal ( Opportunity) & Rating & Weight & Weighted score \\
\hline $\begin{array}{l}\text { Indonesia cukup kuat di pakaian jadi segmen } \\
\text { menengah khususnya baju muslim }\end{array}$ & 4 & 0.2 & 0.08 \\
\hline $\begin{array}{l}\text { Tanah Abang Central Perdagangan terbesar se } \\
\text { Asia tenggara }\end{array}$ & 4 & 0.2 & 0.08 \\
\hline Pemasaran produk di luar pulau jawa & 2 & 0.03 & 0.06 \\
\hline & & & 0.9 \\
\hline Media Online sedang di gandrungi & 3 & 0.03 & \\
\hline
\end{tabular}

\begin{tabular}{|l|r|r|r|}
\hline Faktor eksternal (Threats ) & Rating & Weight & Weighted score \\
\hline & & & \\
\hline Kenaikan harga bahan baku sering tiba tiba & 4 & 0.2 & 0.08 \\
\hline & & & 0.08 \\
\hline Import barang dari China yang tinggi & 4 & 0.2 & 3.32 \\
\hline Total & 33 & 1 & \\
\hline
\end{tabular}




\section{Hasil Perhitungan SWOT}

1) Faktor internal (Strength) : 1,84

2) Faktor internal (Weaknes) : :1,64

3) Faktor external (Opportunity) : 2, 02

4) Faktor external (Threats) : 1,30

\section{Koordinat Analisis Internal}

(Skor total Kekuatan - Skor Total Kelemahan) : 2

$(1,84-1,64): 2=0,1$

\section{Koordinat Analisis Eksternal}

(Skor total Peluang - Skor Total Ancaman) : 2

$(2.02-1.30): 2=0.36$

\section{Jadi, titik koordinatnya terletak pada $(0,1 ; 0,36)$}

\section{KESIMPULAN DAN SARAN}

Dari hasil perhitungan analisis SWOT yang dilakukan terhadap konveksi Kogaya dapat dilihat bahwa konveksi kogaya masuk pada kategori kuadran I, atau dapat disebut juga berada pada situasi yang sangat menguntungkan. Dimana perusahaan memiliki peluang serta kekuatan yang dapat dimanfaatkan pada keadaan yang tepat. Maka seharusnya strategi yang diterapkan dalam kondisi ini yaitu dengan mendorong kebijakan pertumbuhan yang agresif (Growth Oriented Strategy), antara lain:

1. Prioritas: meningkatkan brand melalui iklan media online yang berbayar antara lain Facebook dan Instagram atau social media lainnya.

2. Faktor Penentu Keberhasilan: memilih kualitas bahan baku dengan harga dibawah pasaran namun memiliki kualitas terpercaya yaitu mencari ke tangan produsen pertama agar bisa bersaing dengan harga import China.

3. Output: Membuat promosi di media social dengan berani tampil beda atau dengan menonjolkan diffrensisi product sehingga akan lebih meningkatkan positioning

4. Outcame: Meningkatnya Jumlah volume Jahitan dan penjualan

5. Impact: Perusahaan Kogaya dapat bersaing dengan product import khususnya China.

Sehingga dalam hal ini setelah dilakukan Analisis SWOT terhadap perusahan Kogaya, dengan kompetitor utama adalah barang dari China, sejatinya perusahaan Kogaya masih bisa terus berkembang dan mampu bersaing di tengah pesatnya persaingan bisnis di dunia.

\section{DAFTAR RUJUKAN}

Aipama, W. (2019). Analisis SWOT Pada PT. Media Pajak Indonesia (TAXMEDIA). Jurnal Ilmu Manajemen Terapan, 1 (1) 182-186.

Buchori, H. A., \& Saladin, D. (2010). Manajemen Pemasaran. Bandung: Linda Karya. 
Fadli, L. H. (2019). Strategic Management Analisis SWOT. Jurnal Ekonomi dan Manajemen Sistem Informasi, 1 (2) 106 -112.

Farida, Prabowo, A., Wardhani, D., \& Husnur, A. (2019). Penguatan Word Of Mouth Melalui Strategi Internal Branding Di Perguruan Tinggi Swasta Indonesia. Jurnal Ilmiah Manajemen, 9, (1), 174-189.

Janiah, S. (2019). Strategic Management EFE-IFE Matrix, Swot Analisis, Competitiv Profil Matrix (CPM) Dan BCG Matrix Pada PT Yamaha. Jurnal Ekonomi dan Majamenen Sistem Informasi, 1 (2) 188-196.

Kotler, P., \& Amstrong, G. (2013). Prinsip-Prinsip Pemasaran, Edisi ke-12. Jakarta: Erlangga.

Kotler, P., \& Keller, K. L. (2009). Manajemen Pemasaran (Jiid 1) (Edisi 3). Jakarta: Erlangga.

Kotler, P., \& Keller, K. L. (2012). Marketing Manajemen. Jakarta : Erlangga.

Maxmanroe. (2020, Januari Senin). Maxmanroe. Diambil kembali dari Maxmanroe.com: https://www.maxmanroe.com

Parashakti, R. D., \& Putriawati. (2020). Pengaruh Keselamatan dan Kesehatan Kerja (K3), Lingkungan Kerja dan Beban Kerja Terhadap Kinerja Karyawan. Jurnal Ilmu Manajemen Terapan, 1, (3), 290-340.

Purba, C. B., Rafiani, \& Ali, H. (2018). The Influence of Competency, Organizational Commitment and Non Financial Compensation on Teacher Performance in SMAN 29 Jakarta. Scholars Journal ofEconomics, Business and Management(SJEBM), 5, (3), 2018.

Studio, A. (2020, Februari Senin). Pendidikan.co.id. Diambil kembali dari Pendidikan.co.id Pengertian Ekspor dan Impor: https://pendidikan.co.id

Sudrajat, A. (2019, Mei Selasa). Detik Finance. Diambil kembali dari DetikFinance.com Pakaian Impor Cina: https://finance.detik.com/industri/d-4548844/pakaian-impor-china-serburi-karena-harga-lebih-murah

Suharto. (2017, September Kamis). Indonesia Investment. Diambil kembali dari Indonesia Investment Population of Indonesia: https://www.indonesiainvestments.com/culture/population/item67

Syahnur, I. (2015, Desember Selasa). Academia.edu. Diambil kembali dari Academia: https://www.academia.edu

Yeni, F., Erwin, G., \& Ali, H. (2019). Analisis Strategi Pemasaran Dalam Menghadapi persaingan bisnis PadaPT. Federal Internasional Finance FIF 
Grup Di Kecamatan Ipuh, Kabupaten Mukomuko. Jurnal Ilmu Manajemen Terapan, 1 (1) 38-54. 